${ }^{6}$ Pettinger, W A, and Mitchell, H C, New England fournal of Medicine, 1975, 292, 1214.

' Katz, F H, et al, fournal of Clinical Endocrinology and Metabolism, 1975, 40, 125.

- Michelakis, A M, and Mizukoski, H J, fournal of Clinical Endocrinology, $1971,33,27$

${ }^{9}$ Christlieb, A R, et al, Proceedings of the Society for Experimental Biology and Medicine, 1968, 128, 841.

10 Skrabal, F, and Czaykowska, W, Klinische Wochenschrift, 1974, 52, 1173.

${ }^{11}$ Boyd, G W, et al, Lancet, 1969, 1, 213.

12 Winer, N, et al, Clinical Endocrinology, 1969, 29, 1168.

${ }^{13}$ Michelakis, A M, and McAllister, R G, fournal of Clinical Endocrinology and Metabolism, 1972, 34, 386.
11 Bravo, E L, Tarazi, R C, and Dustan, H B, Fournal of Laboratory and Clinical Medicine, 1974, 83, 119

${ }^{15}$ Sullivan, J M, Adams, D F, and Hollenberg, N K, Clinical Research, $1973,21,453$.

${ }^{16}$ Louis, W J, et al, Circulation Research, 1974, 35, suppl No 1, p 57.

17 Bühler, F R, et al, New England fournal of Medicine, 1972, 287, 1209.

18 Karlberg, B E, et al, British Medical fournal, 1976, 1, 251.

${ }^{19}$ Skrabal, F, et al, Nieren und Hochdruckkrankheiten, 1976, 5, 1.

${ }^{20}$ Brown, J J, et al, Nephron, 1969, 6, 329.

21 Brown, J J, et al, Lancet, 1974, 2, 320.

22 Padfield, P L, et al, Lancet, 1975, 1, 548.

${ }^{23}$ Schalekamp, M A, et al, Ciba Symposium on Hypertension, Malta 1974, p 147. Horsham, Ciba Laboratories, 1975.

\title{
Enhanced drug metabolism in cigarette smokers
}

\author{
PRUE HART，G C FARRELL，W G E COOKSLEY， L W POWELL
}

effects of pentazocine, ${ }^{13}$ propoxyphene, ${ }^{14}$ and benzodiazepines. ${ }^{14}$ Although a recent study has provided more direct evidence that smoking stimulates drug metabolism by showing increased antipyrine clearance rates in smokers, ${ }^{6}$ these results varied considerably according to the age and other characteristics of the patients and could not be attributed solely to cigarette smoking. Smoking had no effect on diazepam plasma disappearance. ${ }^{15}$ Furthermore, although plasma levels of phenacetin are considerably lower in smokers than in non-smokers after comparable oral doses, there is no change in the plasma disappearance rate, and this probably reflects factors other than enhanced hepatic drug metabolism. ${ }^{16}$

We report here the results of a study designed to assess the effect of cigarette smoking on drug metabolism and to exclude both the influence of genetic variability and the effects of other environmental agents. This was done by studying a group of smokers before and after they had stopped smoking.

\section{Patients and methods}

The subjects studied were all healthy volunteers, some of whom were attending a hypnotherapy "stop-smoking" clinic. All gave informed consent. Subjects were excluded from the study if there was evidence of liver or renal disease or other disorders known to influence hepatic drug metabolism. ${ }^{17-20}$ Each volunteer was carefully questioned about his consumption of tobacco, alcohol, tea, and coffee and his use of pharmaceutical agents that may influence antipyrine half life. Those taking known hepatic microsomal enzyme-inducing drugs were excluded, as were those consuming alcohol in moderate amounts ( $<50 \mathrm{~g}$ ethanol per day). Most smokers smoked more than 20 cigarettes per day, but all consumed at least 11 cigarettes a day or $60-85$ g (2-3 oz) tobacco a week. The non-smokers had not smoked at all for the previous six weeks. The average age of the smokers was 39 years (range 16-63 years) and that of the non-smokers 35 years (range 20-63 years). The subjects in each group were comparable in sex and consumption of coffee, tea, and alcohol.

Plasma or saliva antipyrine half lives, or both, were studied in 42 subjects (17 non-smokers and 25 smokers). Several people were studied more than once to assess intraindividual variability and any difference in apparent antipyrine half life due to different routes of drug administration (oral as opposed to intravenous) or method of sampling (saliva as opposed to plasma). Repeat studies were carried out in a manner identical to the initial studies. Eight smokers were also restudied about two months after they had stopped smoking. These subjects were then asked about changes in their life style other than stopping smoking.

An aqueous solution of antipyrine in a dose of $10 \mathrm{mg} / \mathrm{kg}$ body weight was either injected intravenously over 10 minutes or taken by mouth dissolved in $100 \mathrm{ml}$ of orange juice. Five or more samples of venous blood $(10 \mathrm{ml})$ or fresh saliva $(5 \mathrm{ml})$ were collected at intervals during the next 30 hours. The antipyrine concentration of each sample was

G C FARRELL, MB, MRACP, NH and MRC medical postgraduate research scholar

W G E COOKSLEY, MB, FRACP, senior lecturer (clinical) in medical biochemistry

L W POWELL, MD, FRACP, professor cï medicine 
assayed in duplicate by a gas-liquid chromatographic method based on that described by Prescott. ${ }^{21} \mathrm{~A} 3^{\circ}{ }^{\circ}$ SE- 30 column at $200^{\circ} \mathrm{C}$ was used. After the addition of phenacetin as the internal standard antipyrine was extracted from plasma or saliva into chloroform. Gas-liquid chromatography mass spectrometry studies confirmed that the antipyrine peak contained no hydroxylated metabolites, an important advantage over the commonly used spectrophotometric method."i

The standard error for the assay at a plasma concentration of 64 $\mu \mathrm{mol} / \mathrm{l}(12 \mathrm{\mu g} / \mathrm{ml})$ was $2 \cdot 8^{\circ}$ of the mean. The drug concentrations of plasma or saliva were plotted as a function of time on semilogarithmic paper and the half life of the slope was calculated on a computer by the method of least squares. The precision of the data is reflected by the standard deviation of the slope being $4 \cdot 4 \pm 3 \cdot 3^{\circ}$ (mean $\pm S D$ ) of all values. Statistical analyses were performed with Student's $t$ test (paired or unpaired).

\section{Results}

Plasma and saliva antipyrine disappearance rates were measured simultaneously in 14 people (five smokers and nine non-smokers). The results from the two biological fluids were almost identical $(\mathrm{r}=0.95 ; \mathrm{P}<0.001)$. When eight subjects were studied by both oral and intravenous drug administration the same antipyrine half life was observed $(r=0.97 ; \mathrm{P}<0.001)$. For these reasons we did not distinguish in the analyses between method of sampling and route of administration.

There was a large variation of antipyrine half life among the 42 healthy subjects studied, the range extending from $7 \cdot 1$ hours to $16 \cdot 9$ hours (mean 11.4 hours; see figure). The mean antipyrine half life was lower in smokers than in non-smokers $(P<0.05$; see figure). In these two groups no significant correlation could be found between age or sex and antipyrine half life.

Repeat studies in eight controls-four smokers and four nonsmokers-after an average elapsed time of three months showed negligible change, the mean antipyrine half life changing by only $0 \cdot 1{ }^{\circ}$ (not significant, paired $t$ test; table I).

The results of repeat studies on eight former heavy smokers after an average of two months had elapsed are shown in table II. The eighth patient was studied for a third time a month later because we suspected that she may have used sedative medication between the first and second studies. We therefore emphasised the importance of the study to her and repeated the test. Her third antipyrine half life determination was $27^{\circ}$ ogreater than the first, although the intermediate value was $23^{\circ}{ }_{0}$ lower than the original one (table II). The mean change in antipyrine half life between the first and the last study in these eight subjects was $23^{\circ}{ }_{0}(t=4 \cdot 71 ; \mathrm{P}<0.005$, paired $i$ test $)$.

\section{Discussion}

Our results indicate that cigarette smoking significantly enhances antipyrine disappearance rate. By using subjects as their own controls we excluded many interindividual variables that may affect rates of hepatic drug metabolism. Repeat control studies showed that intraindividual variability accounts for less than $10 \%$ of the initially measured antipyrine half life, and antipyrine itself did not change hepatic antipyrine metabolism.

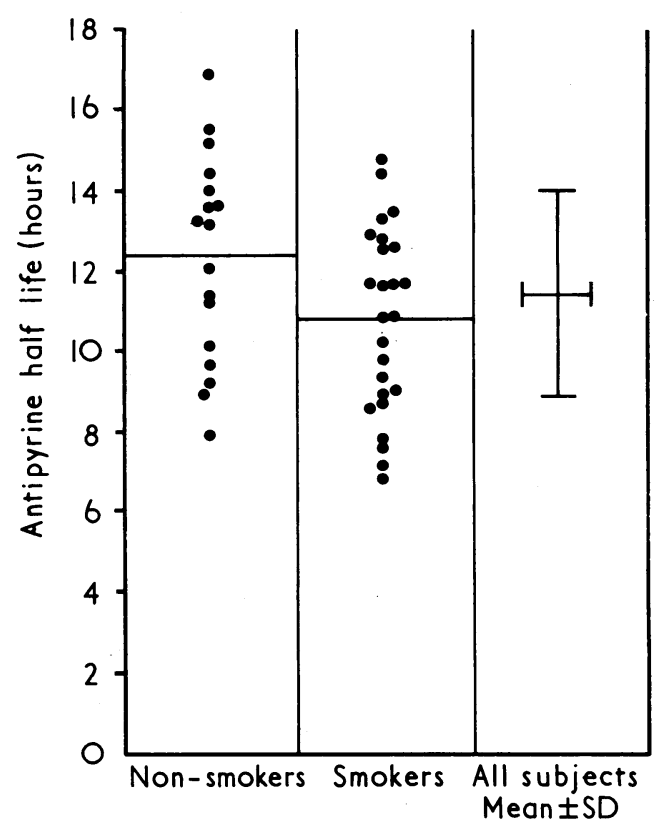

Antipyrine half lives in 17 healthy non-smokers and 25 healthy smokers Horizontal lines indicate means. Mean $\pm S D$ for all 42 subjects is also shown.

We found no change in extrapolated y intercepts of the test drug concentration in repeat studies on both controls and former smokers over two to three months, which indicates that smoking does not alter the biological distribution of antipyrine. We assumed that hypnotherapy per se had no effect on antipyrine half life, although we carried out no studies to validate this. Not all the former smokers were from the hypnotherapy clinic, however (table II).

Antipyrine plasma disappearance rate is an accepted marker for hepatic drug metabolism since both animal and human studies $^{922}{ }^{23}$ have confirmed a close correlation between plasma antipyrine half life and the rate of hepatic antipyrine metabolism. Since antipyrine is rapidly distributed throughout the body and less than $10 \%$ is protein bound, the salivary rate of antipyrine disappearance should closely parallel that of plasma. Our study confirms reports that a very close correlation exists between saliva and plasma disappearance rates ${ }^{24}$ and between oral and intravenous administration of antipyrine. ${ }^{25}$ By showing that these correlations were unaffected by smoking we could offer a more acceptable programme to participants in the study.

Our results provide direct evidence to confirm previous clinical and experimental data that suggested that smoking may affect rates of hepatic drug metabolism. In several of these studies, however, alternative mechanisms may have been operating. Recently it has been shown that antipyrine clearance

TABLE I-Antipyrine half life values (hours) at first and second study and percentage change in values. Subjects 1-4 were non-smokers and subjects 5-8 were smokers

\begin{tabular}{|c|c|c|c|c|c|c|c|c|}
\hline Subject No: & 1 & 2 & 3 & 4 & 5 & 6 & 7 & 8 \\
\hline $\begin{array}{l}\text { 1st Study } \\
2 \text { nd Study } \\
\% \text { Change }\end{array}$ & $\begin{array}{r}13.6 \\
13.1 \\
-3.7\end{array}$ & $\begin{array}{c}15 \cdot 7 \\
15 \cdot 7 \\
0\end{array}$ & $\begin{array}{r}14 \cdot 1 \\
13 \cdot 6 \\
-3.8\end{array}$ & $\begin{array}{r}14 \cdot 1 \\
14 \cdot 7 \\
+4 \cdot 2\end{array}$ & $\begin{array}{r}11.2 \\
12.2 \\
+8.7\end{array}$ & $\begin{array}{r}10 \cdot 7 \\
11 \cdot 0 \\
+3 \cdot 1\end{array}$ & $\begin{array}{r}7.9 \\
7 \cdot 2 \\
-8 \cdot 2\end{array}$ & $\begin{array}{r}12.2 \\
11.9 \\
-1.7\end{array}$ \\
\hline
\end{tabular}

TABLE II-Antipyrine half life values (hours) in eight former smokers

\begin{tabular}{|c|c|c|c|c|c|c|c|c|}
\hline Subject No: & 9* & $10^{*}$ & $11^{*}$ & 12 & 13 & $14^{*}$ & $15^{*}$ & $16 * \dagger$ \\
\hline $\begin{array}{l}\text { 1st Study } \\
\text { 2nd Study } \\
\% \text { Change }\end{array}$ & $\begin{array}{r}12 \cdot 8 \\
15.1 \\
+17.3\end{array}$ & $\begin{array}{r}9 \cdot 0 \\
12 \cdot 2 \\
+35 \cdot 1\end{array}$ & $\begin{array}{r}8.6 \\
11.4 \\
+32.7\end{array}$ & $\begin{array}{r}10 \cdot 2 \\
14 \cdot 4 \\
+41 \cdot 7\end{array}$ & $\begin{array}{r}12.8 \\
13.3 \\
+3.8\end{array}$ & $\begin{array}{r}8.9 \\
10 \cdot 0 \\
+13 \cdot 0\end{array}$ & $\begin{array}{r}7 \cdot 1 \\
7 \cdot 9 \\
+10 \cdot 3\end{array}$ & $\begin{aligned} & 13 \cdot 3 \\
& 10 \cdot 2(16 \cdot 9) \\
- & 23 \cdot 0(+27 \cdot 0)\end{aligned}$ \\
\hline
\end{tabular}


rates are accelerated in smokers. ${ }^{6}$ In this study multiple regression analyses on a large population of patients found a positive correlation of antipyrine clearance with smoking and age. Since this study showed smoking capacity to decrease with age, however, this shortening of antipyrine half life in smokers may be partly due to age differences. Our study was designed to overcome such defects.

Compounds present in cigarette smoke include 3, 4benzpyrene, 3-methylcholanthrene, and many related polycyclic hydrocarbons. ${ }^{11}$ In-vivo animal studies and results from rat fetal liver cell cultures ${ }^{26}$ have shown a direct inducing effect of these hydrocarbons on the hepatic microsomal enzyme oxidising systems. But in our study correlation of changes in antipyrine half life with the number and type of cigarettes smoked and their calculated nicotine and tar contents did not enable us to identify the component of cigarette smoke responsible. This was largely because nicotine levels and tar levels in cigarettes tend to parallel each other thus making it difficult to discriminate between these two components. Variability in the number of puffs per cigarette and the extent of cigarette smoke inhalation may also be important.

The mean increase of $23^{\circ}$ of antipyrine half life on stopping smoking is greater than the $12^{\circ}{ }_{o}$ estimated by Vestal from multiple regression analyses ${ }^{6} ;$ he also found that age contributed $3^{\circ}{ }_{0}$ to interindividual variability while coffee and tea consumption contributed less than $1^{\circ}$. The mean decrease of antipyrine half life was found to be $40^{\circ}{ }_{0}$ in insecticide workers, ${ }^{27} 22^{\circ}{ }_{0}$ in those with a heavy alcohol intake, ${ }^{+} 51^{\circ}{ }^{\circ}$ after 14 days'administration of the hypnotic glutethimide, ${ }^{11}$ and $34 \%$ after $140 \mathrm{mg}$ phenobarbital daily for two weeks. ${ }^{9}$ Since the $23^{\circ} \%$ change in cigarette smoking is comparable with these other well-known inducing agents, we conclude that cigarette smoking is an important factor contributing to the large variation in rates of drug metabolism seen in man.

We thank Mr Chris Leon for allowing us to study patients from his hypnotherapy clinic; Professor B Halpern, University of Wollongong, for performing the gas-liquid chromatography mass spectrometry studies; Mrs Gail Williams for statistical advice; and the Australian Tobacco Research Foundation for financial support. GCF is in receipt of an NH and MRC medical postgraduate research scholarship.

\section{References}

1 Brodie, B B, and Axelrod, A, fournal of Pharmacology and Experimental Therapeutics, 1950, 98, 97.

2 Soberman, R, et al, fournal of Biological Chemistry, 1949, 179, 31.

3 Vesell, E S, and Page, J G, Science, 1968, 161, 72.

${ }^{4}$ Vesell, E S, Page, J G, and Passananti, G T, Clinical Pharmacology and Therapeutics, 1971, 12, 192.

${ }^{5}$ O'Malley, K, et al, British Medical fournal, 1971, 3, 607.

${ }^{6}$ Vestal, R E, et al, Clinical Pharmacology and Therapeutics, 1975, 18, 425.

' Conney, A H, Pharmacological Reviews, 1967, 19, 317.

8 Conney, A H, and Burns, J J, Science, 1972, 178, 576.

${ }^{9}$ Vesell, E S, and Page, J G, Fournal of Clinical Investigation, 1969, 48, 2202.

10 Vesell, E S, and Passananti, G T, Drug Metabolism and Disposition, 1973, 1, 402 .

11 Welch, R M, et al, Clinical Pharmacology and Therapeutics, 1969, 10, 100.

12 Cantrell, E T, et al, fournal of Clinical Investigation, 1973, 52, 1881.

13 Keeri-Szanto, M, and Pomeroy, J R, Lancet, 1971, 1, 947.

14 Jick, H, Medical Clinics of North America, 1974, 58, 1143.

15 Klotz, U, et al, fournal of Clinical Investigation, 1975, 55, 347.

${ }_{16}$ Pantuck, E J, et al, Clinical Pharmacology and Therapeutics, 1974, 15, 9.

1: Andreasen, P B, et al, European fournal of Clinical Investigation, 1974, 4, 129.

${ }^{18}$ Lichter, M, Blacik, M, and Arias, I M, fournal of Pharmacology and Experimental Therapeutics, 1973, 187, 612.

${ }^{19}$ Elin, R J, Vesell, E S, and Wolff, S M, Clinical Pharmacology and Therapeutics, 1975, 17, 447.

20) Ambre, J, et al, Clinical Research, 1974, 22, 598.

${ }^{21}$ Prescott, L F, Adjepon-Yamoah, K K, and Roberts, E, fournal of Pharmacy and Pharmacology, 1973, 25, 205.

22 Statland, B E, et al, Pharmacology, 1973, 10. 329.

${ }^{23}$ Huffman, D H, Shoeman, D W, and Azarnoff, D L, Biochemical Pharmacology, 1974, 23, 197.

${ }^{24}$ Welch, R M, et al, Clinical Pharmacology and Therapeutics, 1975, 18, 249.

${ }^{25}$ Andreasen, P B, and Vesell, E S, Clinical Pharmacology and Therapeutics, $1974,16,1059$.

${ }^{26}$ Nebert, D W, and Gelboin, H V, Archives of Biochemistry and Biophysics, $1969,134,76$.

27 Kolmodin, B, Azarnoff, D L, and Sjoqvist, F, Clinical Pharmacology and Therapeutics, 1969, 10, 638.

\section{SHORT REPORTS}

\section{Computerised axial tomography findings in patients with migrainous headaches}

The demonstration of cerebral oedema by computerised axial tomography (CAT) in patients with migraine was drawn to our attention by Drs J Ambrose and J Gawler of London. The subsequent unexpected finding of a significant degree of cerebral atrophy in a migraine sufferer further prompted our interest in the CAT changes in these patients. The findings in 46 patients with migrainous headaches were therefore reviewed.

\section{Patients, methods, and results}

Thirty women and 16 men with a history of recurrent migrainous headaches for up to 18 years were examined on the EMI scanner, usually because of a change in headache pattern.

The findings are summarised in the table. Small areas of infarction were found in six cases. In four with fixed visual field defects these were in the medial occipital cortex and were bilateral in two; in the other two small clinically unsuspected areas of infarction were found in one temporal lobe. Two patients without known intellectual dysfunction showed a significant degree of cerebral atrophy. One was a 35-year-old woman who had had classical migraine for several years, and the other was a 36-year-old woman who had had mitral stenosis and intractable migrainous headaches for 10 months. Six other patients showed appearances suggestive of very early cerebral atrophy. Twenty-one patients showed appearances compatible with mild cerebral oedema-namely, increased blackening on the Polaroid photograph and scattered matrix cells with $\mu$ values of two or more less than contiguous cells. These appearances were most common in the frontal white matter, being bilateral in 15, unilateral in four, and more extensive throughout the hemisphere on the side of the headache and contralateral to the sensory aura or signs, or both, in two (see table). Seven of these patients were scanned during a migraine attack. Clinically unsuspected gliomas were found in two patients, one with common migraine and one with a classical visual aura.

Focal neurological symptoms and signs in patients with normal and abnormal $C A T$ findings

\begin{tabular}{|c|c|c|c|c|c|}
\hline CAT findings: & Normal & Infarcts & Oedema & Atrophy & Tumour \\
\hline $\begin{array}{l}\text { No of patients } \ldots \\
\text { No with visual or other sensory }\end{array}$ & 9 & 6 & 21 & 8 & 2 \\
\hline $\begin{array}{ccc}\text { aura } & \ldots & \cdots \\
\text { No with focal signs* } & \ldots & \ldots\end{array}$ & & $\begin{array}{l}4 \\
4\end{array}$ & $\begin{array}{l}6 \\
8\end{array}$ & $\begin{array}{l}2 \\
1\end{array}$ & $\begin{array}{l}1 \\
1\end{array}$ \\
\hline
\end{tabular}

*Visual field defect or lateralised motor, sensory, or reflex changes.

\section{Discussion}

While the demonstration of areas of infarction in the visual cortex in patients with fixed visual field defects was not unexpected, the finding of small clinically silent areas of infarction in the temporal lobe in two patients does suggest that focal cerebral damage due to migrainous vasospasm may occur more often than is appreciated. 